\title{
MATERIALIEN
}

WIENER SLAVISTISCHES JAHRBUCH, Band 56/2010, 173-192

(C) 2010 by Österreichische Akademie der Wissenschaften, Wien

Michael Reichimar

\section{Slavica (Slovenica) Admontensia}

Der „offizielle“ Bestand der Admonter Stifts-Bibliothek umfasst ca. 155.000 Bände, 65 laufende Zeitschriften, 1.400 Handschriften, 530 Inkunabeln, 2.000 amtliche Schriften, 200 Landkarten, 800 Mikroformen, 854 Filme, 2.000 Porträts aus dem 16. -19 . Jh. Den kostbarsten Schatz bilden dabei mehr als 1.400 Handschriften (ab dem 8. Jahrhundert) sowie die 530 Inkunabeln (Frühdrucke bis zum Jahr 1500).

Für Slawisten interessant ist zunächst die prominente „Biblia sacra, ebraice, chaldaice, graece, latine, germanice, sclavonice“. In dieser sechssprachigen „HutterBibel“ (Nürnberg 1599) steht unter der Rubrik „sclavonicae“ der slowenische Text aus der Dalmatin-Bibel 1584.

Als ich mich vor einiger Zeit im Katalograum der Bibliothek umschaute, stieß ich auf eine kleine Schachtel mit der Aufschrift „Katalog: Slovenische (jugoslavische) Literatur". Auf meine Nachfrage erklärte mir der Archivar und Bibliothekar des Klosters, Dr. Johann Tomaschek, dass es sich dabei um Bücher aus den Nachlässen von Patres aus der ehemaligen Untersteiermark handelt, die nicht im Hauptkatalog, sondern in einem Katalog des Archivs verzeichnet werden. Er bot mir an, die von den steirisch-slowenischen Benediktinerbrüdern des 19. Jahrhunderts gesammelten slowenischen (und in geringem Umfang kroatischen) Werke zu sichten. Eine Woche lang tauchte ich im Tiefgeschoss des Stiftes in die (Bücher-)Welt der „slowenischen Admonter“ ein. Sie hinterließen an die 500 Druckwerke, die seit mehr als 100 Jahren im Stiftsarchiv aufbewahrt werden. In einem ersten Schritt verglich ich den Katalog mit dem tatsächlich noch vorhandenen Bestand und erfasste diesen bibliographisch. Bald stellte sich heraus, dass sich durchaus nicht nur religiöse Literatur darunter befindet, sondern auch viele natur-, sprach- und kulturwissenschaftliche Kostbarkeiten, z. B. die volkskundlichen Studien zum Geistesleben der steirischen Slowenen von Josef Pajek (Ljubljana 1884), die von Karl Štrekelj gesammelten slowenischen Volkslieder „Slovenske narodne pesmi“" (12 Bände, Ljubljana 1895-1908) und vieles Ähnliches mehr. 
Wer waren nun die slowenischen Patres in Admont? Im Mitgliederverzeichnis der Matica Slovenska, einer im Jahre 1864 in Laibach gegründeten Buchgemeinschaft, findet sich für das Jahr 1868 folgende Aufstellung:

\section{„Razvrstitev Matičnih udov [...] \\ VII. Udje raznih škofij. \\ (Kraji v abecednem redu.)}

1. Admont - Poverjenik: Pivec o. Maksimilijan.

* Lajh o. Korbinijan.

* Matevžič o. Eginard.

* Pivec o. Maksimilijan.

* Vagaja o. Rudolf.

Baumgartner o. Beno kapitular.

Rešek o. Enrik, bogosl. profesor.

Šlander o. Emeran.

Švarc o. Alkuin, kaplan

Trček o. Egidij. “”

Bei den mit* gekennzeichneten Patres handelt es sich um Gründungsmitglieder der Matica Slovenska. Dem Familiennamen folgt jeweils der Ordensname und diesem gegebenenfalls das kirchliche Amt oder der Beruf des Genannten.

Diese 9 Benediktinerpatres stammten aus verschiedenen Orten der damaligen Steiermark und Krains, zum Beispiel der an erster Stelle genannte Vertrauensmann Maximilian Pivec (Pivc) aus steirisch Reifnigg / Ribnica oder Ägidius Trček aus Möttling / Metlika.

Kirchenrechtlich zu Admont gehörig waren zu jener Zeit folgende untersteirische Pfarren: Jarenina / Jahring, Svečina / Witschein, Sveti Jakob / St. Jakob in Windischbüheln, Sveti Jurij / St. Georgen an der Pössnitz, Sveti Jurij / St. Georgen in Windischbüheln, Sveti Lenart / St. Leonhard, Spodnja sveta Kungota / Unter St. Kunigund, Šentilj / St. Egid in Windischbüheln.

Admont hatte darüber hinaus Besitzungen in den Gemeinden Jarenina / Jahring, Ljutomer / Luttenberg, Gornja Radgona / Oberradkersburg und Racji dvor / Razerhof.

Für das Jubiläumsjahr 1874 (800-Jahr-Feier des Benediktinerstiftes Admont) wurde von Pater Florian Kinnast ein Personalstands-Schematismus zusammengestellt und veröffentlicht ${ }^{2}$, der zwar außer den genannten vier Gründungsmitgliedern nur noch P. Heinrich Rešek als Mitglied der Matica Slovenska anführt, die fünf Genannten jedoch (mit zwei weiteren: P. Sigismund Galla und P. Ernest Lorber) auch als Mitglieder der St. Hermagoras-Gesellschaft (Družba svetega Mohorja) aus-

1 Slovenska Matica (Hrsg.), Národni koledar, sporočilo in letopis Matice Slovenske za leto 1869, Ljubljana 1868, S. 79.

2 F. Kinnast (Hrsg.), Album Admontense seu Catalogus religiosorum Ordinis S. P. Benedicti in Abbatia Admontensi Superioris Stiriae anno jubilaeo 1874, Graz 1874. 
weist. Das war eine 1851 in Klagenfurt gegründete Buchgemeinschaft (später mit eigener Druckerei) mit dem Ziel,

„, in slowenischer (windischer) Sprache [...] nützliche, erbauliche Volks- und Prämienbücher zu verfassen, in den Druck zu legen und um den möglichst billigsten Preis unter das Volk zu bringen. ${ }^{\circ 3}$

So hatte es bereits 1845 der spätere Bischof des Bistums Lavant, Anton Martin Slomšek, formuliert und mit den Vereinsstatuten (vorerst vergeblich) bei den Zentralbehörden in Wien eingereicht.

In den genannten Quellen finden sich also elf Patres im Stift Admont, die als Mitglieder einer oder auch beider slowenischer Buchgesellschaften aufscheinen.

1878, fünf Jahre nach der Veröffentlichung des Jubiläums-Schematismus, unterzeichneten die „Slowenen im Stift Admont“ ein Glückwunschtelegramm anlässlich des 70. Geburtstages von Janez Bleiweis, dem „Vater der Heimat, Liebling des Volkes und Erwecker slavischen Bewusstseins, Förderer der Volksveredelung, Ruhm und Stolz des Slaventums“, wie es in dem Schreiben unter anderem heißt:

„Telegrami.

a) Od Slovencev.

Admont. - Očetu domovine, ljubljencu naroda, a zbuditlju slovenske zavesti, pospeševatelju narodnega oblaženja, diki in ponosu Slavjanstva, čestitajo o priliki njegovega sedemdestletnega rojstvenega dneva

Slovenci Benediktinskega zavoda v Admontu. “4

Ende der siebziger Jahre des 19. Jahrhunderts lebten im Stift Admont etwa 90 Klosterangehörige, von denen ca. 10\% slowenischer Muttersprache waren und sich als „Slowenen des Benediktinerstifts in Admont“ bezeichneten. Alle der im Jubiläums-Schematismus genannten Matica Slovenska-Mitglieder waren auch Mitglieder der Hermagorasgesellschaft, während umgekehrt die Hermagoras-Mitgliedschaft nicht automatisch eine solche bei der Matica bedeutete.

In der Bibliothek des Benediktinerstifts Admont in der Steiermark wurde in der zweiten Hälfte des 19. Jahrhunderts (vor allem aus den Beständen und Nachlässen der slowenischen Patres) eine Sammlung slowenischer (und kroatischer) Literatur angelegt, die fast vollständig (gesondert katalogisiert) erhalten geblieben ist.

Dieser Bestand wird im Folgenden bibliographiert: Teil 1: „,Katalog: Slovenische (jugoslavische) Literatur ". Dem folgen weitere, für Slawisten und Sprachwissenschaftler interessante Teile der Bibliothek: Teil 2: "Schrank 99“. Die in Teil 2 angeführte Signatur-Nummer bezieht sich also auf den Schrank 99 im Hauptsaal (Galerie).

3 Zitiert nach: Festschrift zur Eröffnung des Modestusheimes in Klagenfurt am 17. November 1984, Klagenfurt / Celovec 1984, S. 16 (Faksimile).

4 Anton Bezenšek (Hrsg.), Svečanost o priliki sedemdesetletnice Dr. Janeza Bleiweisa dne 19. novembra 1878. Z uvodom Dr. Fr. J. Celestin-a, Zagreb 1879, S. 59. 
Aus dem Hauptkatalog der Stiftsbibliothek Admont füge ich hier noch weitere Werke hinzu: Teil 3: Kleine Auswahl weiterer slavischer bzw. sprach- und landeskundlich interessanter Bücher aus dem Hauptkatalog der Stiftsbibliothek in Admont.

Die Bücher und Zeitschriften lassen schon durch ihre Auswahl, durch ihr Vorhandensein, Rückschlüsse auf das kulturelle Umfeld und die sprachlichen Verbindungen der „slowenischen Patres“ in Admont zu. Neben der Mitgliedschaft in den zwei bereits genannten slowenischen Buchgemeinschaften (Družba svetega Mohorjeva und Slovenska Matica) belegt auch die ihnen zur Verfügung stehende Literatur die Interessen und das Engagement in den für die Slowenisch sprechende Bevölkerung damals (in der zweiten Hälfte des 19. Jahrhunderts) wichtigen Themen, wie zum Beispiel „Illyrismus“, „Panslavismus“ oder „ABC-Krieg“. Man beachte in diesem Zusammenhang den großen Anteil an Werken nicht kirchlich-religiösen Inhalts.

Dem Bibliothekar und Archivar im Benediktinerstift Admont, Dr. Johann Tomaschek, danke ich für seine Unterstützung und wertvolle Hinweise.

Der Zustand der Drucke und ihre Beschreibung in der anschließenden Bibliographie lässt sich wie folgt skizzieren: Mit wenigen Ausnahmen sind die Bücher und Zeitschriften gut erhalten. Ihre Größe wird (mit wenigen Ausnahmen) nicht gesondert angegeben, da sie zum überwiegenden Teil in Oktav-Format (d. h. 18 bis $25 \mathrm{~cm}$ Höhe) vorliegen, z. T. in noch unbeschnittenem Zustand. Einige wenige Bücher bzw. Zeitschriften sind größer $\left(4^{\circ}\right)$.

Der Großteil (vor allem der in Teil 1 angeführten Werke) liegt im originalen, broschierten Einband (mit Schmutztitel) vor. In diesem Fall folgt kein gesonderter Eintrag. Wenn es sich um Bände mit festem Einband (aus Karton, Pappe) handelt, lautet der Vermerk „Fester Einband“.

Da die unter Teil 3 angeführten Werke nur aufgrund der Kartei zusammengestellt, jedoch nicht kollationiert wurden, fehlen hier auch nähere Angaben zum Zustand der Bücher.

Zusammenfassend lässt sich feststellen, dass in der Stiftsbibliothek Admont unerwartet viele slawistisch-philologisch bzw. allgemein-sprachwissenschaftlich relevante Werke vorhanden sind. Ein Teil davon ist den folgenden Aufstellungen zu entnehmen.

Stiftsarchiv, Stiftsbibliothek, 8911 Admont

Internet: http://www.stiftadmont.at/

Benützung der Archiv- und Bibliotheksbestände nach Vereinbarung mit dem Archivar und Bibliothekar Dr. Johann Tomaschek, Tel. +43 (0)3613-2312-602.

Die Admonter Stiftsbibliothek ist auch ohne Führung zu besichtigen! 


\section{Slavica (Slovenica) Admontensia}

\section{Teil 1: Der Katalog „,Slovenische (jugoslavische) Literatur“}

(Abkürzungen: Hrsg. = Herausgeber; S. = Seitenanzahl; in eckigen Klammern: Übersetzung, Kommentar oder sonstige Erläuterungen d. Verf.; Nr. = Inventarnummer im Katalog „Slovenische (jugoslavische) Literatur"; N = Nicht vorhanden. Slovenska Matica: siehe unter Matica Slovenska)

J. Aljaž (Hrsg.), Slovenska Pesmarica. Družba svetega Mohorja. Celovec 1900. 220+4 S. [Liederbuch] Nr. 139.

J. Andrejka, Slovenski fantje v Bosni in Hercegovini 1878. Ob petindavajsetletnici bosenske zasedbe, 1. snopič. Družba sv. Mohorja v Celovcu. Celovec 1904. 208 S. Nr. 1a.

J. Andrejka, Slovenski fantje v Bosni in Hercegovini 1878. Ob petindvajsetletnici bosenske zasedbe, 2. snopič. Družba sv. Mohorja v Celovcu. Celovec 1905. 176 S. Nr. 1b.

Angeljček. Otrokom prijatelj, učitelj in voditelj, 3. zvezek. Hrsg. v. A. Kržič. Katoliška Tiskarna. Ljubljana 1887. Nr. 2.

Angeljček. Otrokom prijatelj, učitelj in voditelj, 4., 5., 6. tečaj. Hrsg. v. A. Kržič. Ljubljana $1896,1897,1898$. Nr. 2.

J. Apih, Slovenci in 1848. leto. Matica Slovenska. Ljubljana 1888. 302+4 S. Fester Einband. Nr. 4.

J. Apih, Naš cesar. Spomenica ob 50-letnici njegove vlade. Družba sv. Mohorja. Celovec 1898. 208 S. Nr. 3.

G. Arnold, Izabrane pjesme. Zabavna knjižnica Matice Hrvatske. Matica Hrvatska. Zagreb 1899. Nr. 130.

I. Baloh, C̆rtice. Samozaložba. Kamnik 1905. 184 S. Nr. 5.

F. Baraga, Dušna paša za kristjane, ki želé v duhu in v resnici moliti Boga. Družba sv. Mohorja v Celovcu. Celovec 1905. 416 S. Nr. 6.

A. Bauer, (Zagrebački) Priručnik rimskoga obrednika. Zagreb 1933. 320 S. Fester Einband. Nr. 162.

F. Baš, Janko Glaser et al. (Hrsg.), Časopis za zgodovino in narodopisje (ČZN), št. 34/1939. 256+14 S. Nr. 7.

F. Bevk, Stražni ognji. Povest. Slovenskih Večernic 84. zvezek. Družba svetega Mohorja. Celje 1931. 159 S. Nr. 241.

A. Bezenšek, Bolgarija in Srbija. Družba sv. Mohorja. Celovec 1897. 237+3 S. Nr. 8.

A. Bezenšek (Hrsg.), Svečanost o priliki sedemdesetletnice Dr. Janeza Bleiweisa dne 19. novembra 1878. Z uvodom Dr. Fr. J. Celestin-a. Zagreb 1879. 96+1 S. Nr. 9.

J. Bilc, Tarbula, devica mučenica. Samozaložba. Ljubljana 1899 (1901). 49+2 S. Nr. 10.

J. E. Bíly, Zgodovina svetih apostolov slovanskih Cirila in Metoda. Janez Majciger. Prag 1863. 105 S. Nr. 233a. 124.

M. Bogović, Pjesnička djela. Pripoviesti. Matica Hrvatska. Zagreb 1894. 347+1 S. Nr.

F. Bradač, Ivan Pregelj, Slovenski nemški slovar. Slovenisch-deutsches Wörterbuch. Jugoslovanska knjigarna. Ljubljana 1930.625 S. Fester Einband. Nr. 11.

J. Brinar, Anton Martin Slomšek kot pedagog. Dragotin Hribar. Celje 1901. 94 S. Nr. 13.

J. Brinar, Lisica Zvitkorepka. Živalske pravljice za odrastlo mladino. Slovenskih Večernic 56. zvezek. Celovec 1904. 143+1 S. Nr. 12.

I. Broz, Stjepan Bosanac (Hrsg.), Junačke pesme. Hrvatske narodne pjesme. Matica Hrvatska. Zagreb 1896. 610 S. [Heft 3 fehlt]. Nr. 126.

H. Burmeister, Načalnoe osnovanie Zveroslovija. Übersetzt von V. A. Voljan'. Wien 1852. 235+12 S. Russisch. Fester Einband. Nr. 223.

V. Car Emin, Pusto ognjište. Zabavna knjižnica Matice Hrvatske. Matica Hrvatska. Zagreb 1900 . Nr. 130.

A. Cebuský, Kurzgefaßte Grammatik der Böhmischen Sprache. Verl. L. W. Seidel. Wien 1850. 180+1 S. Nr. 14.

M. Cigale, Znanstvena terminologija s posebnim ozirom na srednja učilišča. Deutschslovenische wissenschaftliche Terminologie. Matica Slovenska. Ljubljana 1880. 171 S. Nr. 15. 
M. Cilenšek, Naše škodljive rastline v podobi in besedi, 1. - 5. snopič. Družba sv. Mohorja. Celovec 1892-1896. 768 S. Nr. 16.

E. H. Costa (Hrsg.), Vodnikov spomenik. Vodnik Album. Ljubljana 1859. 268+6 S. Fester Einband. Nr. 18.

Cvetje iz domačih in tujih logov. Viljem Tell - 1. zvezek. Übersetzt aus dem Griechischen von Ivan Božič. Celovec 1862. Nr. 19. N. N.

Danica. Cerkveni list za vse slov. pokrajine, 1. letnik, list 1-52. Ljubljana 1903. Nr. 20.

D. de Foě, Robinson starši, njegove vožnje in čudezne dogodbe. Übersetzt von Janez Parapat. Družba svetega Mohorja. Celovec 1876. 141+2 S. Nr. 151.

Dom in svet. Ljubljana 1900-1905 [laut Katalog vorhanden: 13. Jg. (1900): 1-19, 14. Jg. (1901): 10, 11, 12, 15. Jg. (1902): 1-12, 16. Jg. (1903): 1-12, 17. Jg. (1904): 1-12, 18. Jg. (1905): 1]. Nr. 22. N.

Drobtinice. Hrsg. v. J. Rozman. Celovec 1851. Nr. 13.

Drobtinice. Hrsg. v. F. Lampe. Ljubljana 1887-1893. Nr. 23. N.

Družba svetega Mohora (Hrsg.), Koledarček družbe svetega Mohora za prestopno leto 1868, 1872. Celovec 1867, 1871. Nr. 137.

Družba svetega Mohora (Hrsg.), Mati Božja dobrega svèta ali bratovska ljubezen. Slovenskih vecernic 17. zvezek. Družba svetega Mohorja. Celovec 1868. 119+1 S. Nr. 135.

Družba svetega Mohora (Hrsg.), Koledarček družbe svetega Mohora za navadno leto 1869, 1870, 1871. Celovec 1868, 1869, 1870. Nr. 137.

Družba svetega Mohora (Hrsg.), Koledar družbe svetega Mohora za leto 1873, 1874, 1875, 1877, 1880, 1881, 1882, 1885. Celovec 1872, 1873, 1874, 1876, 1879, 1880, 1881, 1884. [1876, 1883, 1884 fehlt]. Nr. 136.

Družba svetega Mohora (Hrsg.), Koledar družbe svetega Mohor(j)a za leto 1887, 1888, 1890, 1891, 1892, 1893, 1894. Celovec 1886, 1887, 1889, 1890, 1891, 1892, 1893. [Koledar za 1. 1891 fehlt]. Nr. 136a.

Družba svetega Mohorja (Hrsg.), Koledar družbe svetega Mohorja za leto 1897, 1898, 1899, 1900, 1901, 1902, 1903, 1904, 1905, 1906, 1907, 1908, 1909. Celovec 1896, 1897, 1898, 1899, 1900, 1901, 1902, 1903, 1904, 1905, 1906, 1907, 1908. Nr. 136b.

Družba svetega Mohora (Hrsg.), Slovenske Večernice za poduk in kratek čas. Sèstavil in družnikom sv. Mohora za Večernice podal Janez Ev. Marinič. Celovec 1872. 110+1 S. Nr. 141.

Družba svetega Mohorja (Hrsg.), Slovenske Večernice za pouk in kratek čas. Celovec 1890. 127+1 S. [Beiträge von: I. Križanič, P. Velimir, J. M. Kržišnik, R. Čuček, J. Leban, I. Steklassa, J. Barlè, J. Podboj, A. Koder, I. St., A. Benedik]. Nr. 141.

Družba svetega Mohorja (Hrsg.), Slovenske Večernice za pouk in kratek čas. Celovec 1900. 143+1 S. [Beiträge von: F. Malograjski, A. Medved, Fr. Ks. Meško, J. Trunk, J. Kostanjevec, J. M. Dovič, Podvranski, J. Krenčnik]. Nr. 141.

Družba svetega Mohorja (Hrsg.), Slava Gospodu! Molitvenik. Celovec 1902. 378+6 S. Nr. 140.

Družba svetega Mohorja (Hrsg.), Slovenska Pesmarica. Slovenska Pesmarica. Celovec 1896. $205+3$ S. [Liederbuch]. Nr. 139. Duhovni pastir. (Hrsg. v. Kržič-Stroj). 1893-1900 [Vorhanden: Jg. 10: 11, Jg. 11: 5-12, Jg. 12: 1-12, Jg. 13: 1, 2, 3, Jg. 14: 5-7, 10-12, Jg. 15: 1-12, Jg. 16: 1-12 (außer 10), Jg. 16 (17?): 6, 7]. Nr. 24. N.

Duhovni pastir, 4.-14. letnik. Hrsg. v. A. Kržič und A. Stroj. Ljubljana 1887-1897. [Hrsg. v. Bd. 10: A. Stroj]. Nr. 84. N.

F. Dulár, Domači Živinozdravnik. Družba sv. Mohorja. Celovec 1890. 221+3 S. Nr. 26.

F. Dulár, Umna živinoreja, 1. in 2. knjiga. Družba sv. Mohorja. Celovec 1894, 1895. 204+4 (1), 205+3 (2) S. Nr. 25.

Elegia pripoštovanomu Franji Kolungjichu. Budim 1826. Nr. 27. N.

F. Erjavec, Rudninoslovje ali mineralogija za niže gimnazije in realke. Matica Slovenska. Ljubljana 1867. 88+8 S. Nr. 29.

F. Erjavec, Domače in tuje Živali v podobah. Slovenskih Večernic 18., 20., 22., 25., 30. zvezek. Družba sv. Mohora. Celovec 1868, 1869, 1870, 1871, 1873. Nr. 30.

F. Erjavec, Naše škodljive živali v podobi in besedi, 1. in 3. snopič. Družba sv. Mohorja. Celovec 1880, 1882. $(328+8)$ S. [Heft 2 fehlt]. Nr. 28. 
L. Ferčnik (Hrsg.), Slovenski Goffine ali Razlaganje cerkvenega leta. Celovec 18781881. 928 S. Nr. 31.

A. Foerster, Cecilia. Cerkvena pesmarica. Družba sv. Mohora. Celovec 1883, 1884. 407+4 S. Nr. 32.

I. Fürst, Kraljević Radovan. Zabavna knjižnica Matice Hrvatske. Zagreb 1897. Nr. 130.

E. Gangl, Véliki trgovec. Slovenskih Večernic 54. zvezek. Družba sv. Mohorja. Celovec 1902. 224 S. Nr. 33.

I. Geršak, Čitavnica. Podučivni list za slovenski narod. Leuschner in Lubenski. Gradec 1865, 1866. (368 S.) [Heft 1 fehlt]. Nr. 34.

K. Š. Gjalski, Diljem doma. Zabavna knjižnica Matice Hrvatske. Zagreb 1899. Nr. 130.

S. Gjurašin, Ptice. Prirodopisne i kulturne crtice. Poučna knjižnica Matice Hrvatske, knjiga 24. Zagreb 1899. $318 \mathrm{~S}$, mit $107 \mathrm{Abb}$. Nr. 35.

K. Glaser, Zgodovina slovenskega slovstva. Ljubljana 1894, 1895, 1896, 1898. 217, 276+5, 338+3, 483 S. [komplett]. Nr. 36.

K. Glaser (Hrsg.), Mâlavikâ in Agnimitra. Indijska drama Kâlidâsova. Zbirka indijskih glediščnih iger, 2. zvezek. Trst 1886 (1885). 100+2 S. Nr. 37.

J. Godec, Lurska mati božja. Šmarnice in molitvenik. Družba sv. Mohorja. Celovec 1904. $348+4$ S. Nr. 38.

W. Goethe, Faust, prvi del. Prevodi iz svetovne književnosti. Übersetzt von Anton Funtek. Slovenska Matica. Ljubljana 1908. 200 S. Nr. 39.

N. Gogol, Mrtve duše. Übersetzt von Podgoriški. Ljubljana 1887. Nr. 155.

N. V. Gogol, [Unveröffentlichte Texte, Briefe etc.]. Literarnji arhiv. Akademija Nauk SSSR. Russisch. Moskau, Leningrad 1936. 502 S. Fester Einband. Nr. 248.

J. Gomilšak, Potovanje v Rim. Družba sv. Mohora. Celovec 1878. 176 S. Nr. 40.

F. Govekar, Umni živinorejec s posebnim ozirom na govedje. Slovenskih Večernic 27. zvezek. Celovec 1872. 94+2 S., Beilage mit 13 Abb. Nr. 41.

S. Gregorčič, Poezije. Hrsg. v. I. Gruntar. Ljubljana 1882. 158+2 S. Nr. 42.

T. S. J. Gregorčič, Duhovna samota. Rudolfovo 1890 . Nr. 44. N.

S. Gregorčič, Poezije. Družba sv. Mohorja. Celovec 1908. 141+3 S. Nr. 43.

L. Grossman, Žizn' i trud' F. M. Dostoevskogo. Moskau, Leningrad (1936). 375+5 S. Russisch (Biographie F. M. Dostoevskijs). Nr. 250.

I. Gršak, Slovenski Štajer. Dežela in ljudstvo. Slovenska Matica. Ljubljana 1868, 1870. 118, 137 S. Nr. 45.

O. Hadžić Ivan Milićević (= Osman-Aziz), Bez nade. Zabavna knjižnica Matice Hrvatske. Zagreb 1895. Nr. 130.

O. Hadžić Ivan Milićević (= Osman-Aziz), Bez svrhe. Slika iz života. Zabavna knjižnica Matice Hrvatske. Zagreb 1897. Nr. 130. 130.

A. Harambašić, Izabrane pjesme. Zabavna knjižnica Matice Hrvatske. Zagreb 1895. Nr.

G. Heser, Život Gospodina našega Isusa Krista kako ga četiri evangjelista opisuju. Aus dem Lateinischen von Josip Stadler. Društvo sv. Jeronima. Zagreb 1895. 210+5 S. Nr. 194.

I. Hoić, Slike iz obćega zemljopisa (Rusija). Poučna knjižnica „Matice Hrvatske“, knjiga 23. Zagreb 1898, 1900. 397+2 S., 456+5 S. Nr. 46a, 46b.

A. Homan, Postrežba bolnikom. Družba sv. Mohorja. Celovec 1899. 95+1 S. Nr. 47.

D. Hribar (Hrsg.), Ilustrovani Narodni koledar za leto 1900, 1901, 1903. Celje 1899, 1900, 1902. 141+30 S., 147+30 S., 123+30 S. Fester Einband. Nr. 49, 49a, 49b.

F. Hrovat, Franc Pirec. Oče umne sadjereje na Kranjskem in apostolski misijonar med Indijani v severni Ameriki. Družba sv. Mohora. Celovec 1887. 111+1 S. Nr. 50.

F. Hubad, Junaki. Knjižnica Družbe sv. Cirila in Metoda. Ljubljana 1889. Nr. 17.

F. Ilešič, Kultura in politika. Matica Hrvatska in Matica Slovenska. Zagreb 1908. 18 S. Nr. 54.

F. Ilešič (Hrsg.), Hrvatska knjižnica. Matica Slovenska. Ljubljana 1906. 104 S. Nr. 55.

F. Ilešič (Hrsg.), Hrvaška knjižnica. Matica Slovenska. Ljubljana 1906. 102 S. Nr. 55a.

F. Ilešič (Hrsg.), Trubarjev Zbornik. Matica Slovenska. Ljubljana 1908. 293+1 S. Nr. 56.

V. Jagić, Ruska književnost u 18.stoljeću. Matica Hrvatska. Zagreb 1895. 284 S. Nr. 57.

F. Jančar, Umni vinorejec. Slovenskih večernic 16. zvezek. Družba sv. Mohora. Celovec 1867. 96 S. Nr. 52. 
F. Jančar, Umni gospodar ali gospodarsko berilo. Družba sv. Mohora. Ljubljana 1869. $212+3$ S. Nr. 53.

F. Jaroslav, Dr. Ignacij Knoblehar, apostolski provikar v osrednjej Afriki. Družba sv. Mohora. Celovec 1881. 96 S. Nr. 58.

J. Jesenko, Prirodoznanski zemljepis. Matica Slovenska. Ljubljana 1874. 399+5 S. Fester Einband. Nr. 51.

Jug [Zschr. „Der Süden“], Hrsg. v. F. Derganc, št.1-5. Dunaj 1901. 168 S. Nr. 21.

J. Jungmann (Hrsg.), Časopis k prospěchu času priměrených oprav na gymnasiích. Übersetzt von Eduard Váněk. Prag 1849. [Nur Heft 6 und 7 vorhanden. Tschechisch-deutsch]. Nr. 242.

J. Kalan, Početek protialkoholnega gibanja na Slovenskem. Knjižnica slov.kršč.soc. zveze. Ljubljana 1902. Nr. 59. N.

A. Karlin, V Kelmorajn. Potopisne črtice s slikami. Družba sv. Mohorja. Celovec 1903. $175+1$ S., mit zahlr. Fotografien. Nr. 60 .

Katoliški obzornik. 1897-1899, 1903-1906 [Vorhanden: Jg. 1 (1897): 2, 3, 4, Jg. 2: 1, 2 , 3, 4, Jg. 3: 1, 2, 3, 4, Jg. 7 (1903): 3, Jg. 8: 1, 2, 3, 4, Jg. 9: 1, 2, 3, Jg. 10 (1906): 2, 3]. Nr. 62. N.

T. Kempčan, Hodi za Kristusom! Družba sy. Mohora. Celovec 1888. 402+14 S. Nr. 61.

V. Klaić, Bribirski knezovi od plemena Šubić do god. 1347. Matica Hrvatska. Zagreb 1897. 176 S., mit Beilage [Rodoslovlje/Stammbaum]. Nr. 63.

L. Klofutar, Svete listne bukve katoliške cerkve, ali razlaga in dejanska obravnava vseh listov, ki se berejo ob nedeljah in zapovedanih praznikih celega leta. Lastna založba. Ljubljana $1878.310+9$ S. Nr. 64

Š. Kociančič, G. Erhard (Hrsg.), Kristusovo življenje in smert v premišljevanjih in molitvah. Družba sv. Mohora. Celovec 1868-1877. Nr. 66.

F. Kočevar, Kupčija in obrtnija. Denar in blago. Družba sv. Mohora. Celovec 1872. $215+1$ S. Nr. 65.

J. Koprivnik, Domači vrtnar. Družba sv. Mohorja. Celovec 1903. 140+4 S. Nr. 67.

L. Kordeš (Hrsg.), Ljudska knjižnica. Maribor [1884-1885]. [10 Hefte vorhanden: 1, 2, 3, $4,7,8,9,14,16,23]$. Nr. 68.

S. Korenić, Čovjek od ženidbe do smrti. Nach Alban Stolc. Društvo sv. Jeronima. Zagreb 1895. 67 S. Nr. 195.

F. Kos, Spomenica tisočletnice Metodove smrti. Matica Slovenska. Ljubljana 1885. 174+2 S. Nr. 69.

F. Kos, Doneski k zgodovini Škofje Loke in njenega okraja. Matica Slovenska. Ljubljana 1894. $368+1$ S. Nr. 71.

F. Kos, Gradivo za zgodovino Slovencev v srednjem veku. Prva kniga, 1. 501-800. Leonova družba. Ljubljana 1903. 415+1 S. Nr. 70.

F. Kosec, Katoliško zakonsko pravo z ozirom na državne avstrijske postave. Založba Katol. Bukvarne. Ljubljana 1894. 248 S. Nr. 72.

A. Kosi, Umni kletár. Družba svetega Mohorja. Celovec 1901. 126+2 S. Nr. 74.

A. Kosi (Hrsg.), Zabavna knjižnica za slovensko mladino. Ljubljana 1894-1899 [Hefte 3 $-8]$. Nr. 73.

J. Kostanjevec, Življenja trnjeva pot. Resnična zgodba iz polupreteklega časa. Družba svetega Mohorja. Celovec 1907. 111 S. Nr. 75.

F. Kovačič (Hrsg.), Voditelj v bogoslovnih vedah. Maribor 1908, 1909. 444+7, $220 \mathrm{~S}$. [Jeder Jahrgang mit 4 Heften. Vorhanden Jgg. 11 und 12, von Jg. 12 nur Hefte 1 und 2]. Fester Einband. Nr. 219.

F. Kovačič (Hrsg.), Časopis za zgodovino in narodopisje. Leto 26. Zgodovinsko društvo v Mariboru. Maribor 1931. 296+79 S. [Teilw. Fehldruck: Slomšek-Korrespondenz, in: Arhiv za zgodovino in narodopisje. I., S. 17-96] Nr. 76.

A. Kralj, Obrtni red, v: Knjižnica slov.kršč.soc. zveze, 2. letnik, zv. 1-8. Ljubljana 1903, 1904. Nr. 77. N.

E. Kramer, Kmetijsko berilo za nadaljevalne tečaje ljudskih šol in gospodarjem v pouk. Trst 1887. $245+5$ S. S 83 podobami (mit 83 Abb.). Nr. 78. 130.

S. S. Kranjčević, Izabrane pjesme. Zabavna knjižnica Matice Hrvatske. Zagreb 1898. Nr. 
Kranjsko ribarsko društvo (Hrsg.), Nekoliko besedí o ribarstvu na Kranjskem, kaj ga ovira in kako bi se dalo pouzdigniti. Ljubljana o.J. [nach 1888]. 12 S. Nr. 166.

Kres. Hrsg. v. J. Sket, Trstenjak u.a. Celovec 1881-1886. Nr. 80. N.

I. Križanič, Zgodovina svete katoliške cerkve za slovensko ljudstvo. Družba svetega Mohorja. Celovec 1883, 1885, 1887. 208, 228+4, 230+2 S. Nr. 81.

I. Križanič, Bela žena ali Prva reč med štirimi poslednjimi. Maribor 1890 [1889]. Nr. 82.

J. Krsnik, Zgodovina avstrijsko-ogrske monarhije. Matica Slovenska. Ljubljana 1874. 99 S. Nr. 83 .

A. Kržič, Osmero blagrov na svetu ali dolga pridiga za kratkočasno življenje. Družba svetega Mohorja. Celovec 1887. 190+2 S. Nr. 85a.

A. Kržič, Zbirka lepih zgledov. Ljubljana 1896. Nr. 85. N.

O. Kučera, Naše nebo. Crtice iz astronomije. Matica Hrvatska. Zagreb 1895. 430 S., mit Beil. u. 142 Abb. Nr. 86.

O. Kučera, Vrieme. Crtice iz meteorologije. Matica Hrvatska. Zagreb 1897. 348+3 S., mit 113 Abb. und 6 Karten. Nr. 87.

F. Kuralt, Umni sadjerejec. Družba svetega Mohorja. Celovec 1878. 142+2 S. Nr. 88.

I. Lah, Uporniki. Slovenskih Večernic 58. zvezek. Družba svetega Mohorja. Celovec 1906. 222 S. Nr. 90.

F. Lakmayer, Umni čebelar. Celovec 1908. 122 (129-250) + 6 S. [Vorhanden: nur 2. Heft]. Nr. 89.

F. Lampe, Uvod v modroslovje. Matica Slovenska. Ljubljana 1887. 190+2 S. Fester Einband. Nr. 94.

F. Lampe, Ali je Bog? Apologetični razgovori ali Pot do resnice. Ljubljana 1889. 224 S. [2 Hefte]. Fester Einband. Nr. 93. 92a.

F. Lampe, Dušeslovje. Matica Slovenska. Ljubljana 1889, 1890. 528 S. [2 Hefte]. Nr. 92, Nr. 91.

F. Lampe, Obrambni govori. Katoliška Bukvarna. Ljubljana 1890. 96 S. Fester Einband.

F. Lampe, Dušeslovje. Matica Slovenska. Ljubljana 1890. 528 S. Fester Einband. Nr. 94a.

F. Lampe, Jeruzalemski romar. Družba svetega Mohorja. Celovec 1892, 1893. 366+2 S. [2 Hefte]. Nr. 95.

I. Lavrenčič, Anton Aloizij Wolf, knezoškof Ljubljanski. V spomin stoletnice njegovega rojstva. Ljubljana 1882. 58 S. [Nachdruck aus „Novice“]. Nr. 97.

J. Lavtižar, Pri severnih Slovanih. Potopisne črtice s slikami. Družba svetega Mohorja. Celovec 1906. 191+1 S. Nr. 98.

M. Lendovšek (Hrsg.), Slomšekovi Životopisi. Ant. Mart. Slomšeka zbrani spisi [Slomšekovih zbranih spisov]. Družba svetega Mohorja. Celovec 1879. 397+2 S. Fester Einband. Nr. 99.

M. Lendovšek (Hrsg.), Slomšekovo Različno blago. Ant. Mart. Slomšeka zbrani spisi [Slomšekovih zbranih spisov]. Družba svetega Mohorja. Celovec 1885. 428+4 S. Fester Einband. Nr. 99.

M. Lendovšek (Hrsg.), Ant. Mart. Slomšeka Pastirski listi. Družba svetega Mohorja. Celovec 1890. 254+2 S. Fester Einband. Nr. 100.

M. Lendovšek (Hrsg.), Slomšekove Pridige osnovane. Ant. Mart. Slomšeka zbrani spisi [Slomšekovih zbranih spisov]: Šesta knjiga. Družba svetega Mohorja. Celovec 1899. 455 S. Nr. 99. 101.

A. Lenz, Soustava učení M. Jana Viklifa na základě pramenù. Prag 1898. 228+5 S. Nr.

A. Lesar, Prilike patra Bonaventure. Družba svetega Mohorja. Celovec 1866. 113+2 S. Nr. 102.

J. Leskovar, Propali dvori. Zabavna knjižnica Matice Hrvatske. Zagreb 1896. Nr. 130.

J. Leskovar, Sjene ljubavi. Zabavna knjižnica Matice Hrvatske. Zagreb 1898. Nr. 130.

F. Levstik (Hrsg.), Vodníkove pésni. Matica Slovenska. Ljubljana 1869. 146+2 S. Fester Einband. Nr. 103.

A. M. Liguorski, Priprava na smrt ali premišljevanje večnih resnic. Übersetzt von Andrej Karlin. Družba svetega Mohorja. Celovec 1900. 382+2 S. Nr. 104. 
Ljubljanski zvon. Ljubljana 1884-1898 [Vorhanden: Jg. 4 (1884): 1, 4, 5, 6, 7, 9; Jg. 5 (1885): 1, 2, 4, 5, 6, 7, 8, 9, 10, 11; Jg. 6 (1886): 1, 4, 5, 8, 9, 10, 11, 12; Jg. 7 (1887): 1-12; Jg. 8 (1888): 1-12, 11 fehlt; Jg. 9 (1889): 2-12; Jg. 12 (1892): 1-12; Jg. 17 (1897): 12 Hefte; Jg. 18 (1898): 2 Hefte]. Nr. 105. N.

A. Lobmayer, Čovjek i njegovo zdravlje. Matica Hrvatska. Zagreb 1898. 190 S. Nr. 106.

A. Mahnič (Hrsg.), Rimski katolik. Gorica 1890-1896. Nr. 107. N.

M. Majar Ziljski, Sveta brata Ciril in Metod slovanska apostola. Družba svetega Mohorja. Celovec 1885. 79+1 S. Nr. 233.

J. Majciger, M. Pleteršnik, B. Raić, Slovanstvo. Prvi del: Občni pregled. - Jugoslovani: Slovenci, Hrvati in Srbi, Bolgari. Matica Slovenska. Ljubljana (1873). 354+2 S., mit 2 Karten. Nr. 108.

F. Malograjski, Z viharja v zavetje. Roman iz življenje preproste deklice. Zabavna knjižnica. Slovenska Matica. Ljubljana 1900. 305 S. Nr. 122.

F. Malograjski, Za srečo! Povest. Družba svetega Mohorja. Celovec 1901. 192 S. Nr. 133.

K. V. Mander, Knjiga o hudožnikah. [St. Petersburg 1938]. 378 S. Russisch. Fester Einband. Nr. 247.

V. Marinko (Hrsg.), Zora. Glasilo katoliško-narodnega dijaštva: Po desetih letih (Spominska knjiga „Danice“). Ljubljana 1905. 149+1 S. Nr. 236.

L. Marjanović (Hrsg.), Junačke pesme (Muhamedovske). Hrvatske narodne pjesme. Matica Hrvatska. Zagreb 1899. 736 S. [Mit Glossar S. 666-736]. Nr. 126.

J. Marn, Kopitarjeva spomenica. Matica Slovenska. Ljubljana 1880. 188 S., mit einer Beilage: Brief Kopitars (Faksilmile) vom 10.10.1843. Nr. 113.

J. Marn, Jezičnik. Svitoslav i Danica. Ljubljana 1889. 99 S. Nr. 109.

Matica Hrvatska (Hrsg.), Rjećnik hrvatsko-slovenski. Zagreb 1895. Nr. 131. N.

Matica Hrvatska (Hrsg.), Izvještaj Matice Hrvatske za upravnu godinu 1895, 1896, 1897, 1899. Matica Hrvatska. Zagreb 1896, 1897, 1898, 1900. [4 Jgg.]. Nr. 125.

Matica Hrvatska (Hrsg.), Spomen - Cvieće iz hrvatskih i slovenskih dubrava. Narodnomu dorbrotvoru Biskupu Josipu Jurju Strossmayeru. Matica Hrvatska. Zagreb 1900. 512+1 S. Nr. 128.

Matica Slovenska (Hrsg.), Spomenik o šeststoletnici začetka habsburške vlade na Slovenskem. Ljubljana 1883. $241 \mathrm{~S}$. Großformat. Nr. 95a.

Slovenska Matica (Hrsg.), Národni koledar in letopis Matice Slovenske za leto 1868. Ljubljana 1867. $44+128+68+8$ S. [Enthält: Letopis Matice Slovenske v Ljubljani za leto 1867]. Nr. 116.

Slovenska Matica (Hrsg.), Národni koledar, sporočilo in letopis Matice Slovenske za leto 1869. Matica Slovenska. Ljubljana 1868. 32+96+166+1 S. [Hrsg. des Letopis za leto 1869: Janez Bleiweis]. Nr. 116.

Slovenska Matica (Hrsg.), Slovenski Štajer. Ljubljana 1868, 1870. Nr. 120. N.

Slovenska Matica (Hrsg.), Letopis Matice Slovenske. Ljubljana 1877, 1878. 394, 265+2 S. [Vorhanden: LMS za leto 1877; LMS za leto 1878, 3. in 4. del (Vredil dr. Janez Bleiweis)]. Nr. 112.

Slovenska Matica (Hrsg.), Zabavna knjižnica. Ljubljana 1886-1908. Nr. 122. N.

Slovenska Matica (Hrsg.), Ant. Knezova knjižnica. Zbirka zbavnih in poučnih spisov. Slovenska Matica. Ljubljana 1897. [Nur mehr 1 Heft vorhanden, ursprünglich vorh.: 1/1894 bis 15/1908, außer 8/1901]. Nr. 111.

Slovenska Matica (Hrsg.), Zborniki 1899-1906. Ljubljana 1899-1906. Nr. 123. N.

A. Medved, Knezoškof lavantinski Anton Martin Slomšek. Družba svetega Mohorja. Celovec 1900. 191+1 S. Nr. 132.

F. Miklosich, Lexicon Linguae Slovenicae veteris dialecti. Vindobonae 1850. 204 S. Fester Einband. Nr. 133a.

F. Ž. Miler, Tri vesele igre: Stričeva oporuka. Prva kiša. Začarani ormar. Zabavna knjižnica Matice Hrvatske. Zagreb 1897. Nr. 130.

F. J. Milovršnik, Boj za pravico. Povest. Družba svetega Mohorja. Celovec 1897. 192 S. Nr. 134.

F. Močnik, Navod k pervej in drugej računici za slovenske ljudske šole. Dunaj 1876. 112 S. Nr. 245. 
T. Mraz, Razlaga srednjega in največjega šolskega katekisma. Družba svetega Mohorja. Celovec 1883. 1036 S. [Beilage zu „Slov. Prijatelj“]. Nr. 143.

E. Mulabdić, Zeleno busenje. Zabavna knjižnica Matice Hrvatske. Zagreb 1898. Nr. 130.

E. Mulabdić, Na obali Bosne. Crtice. Zabavna knjižnica Matice Hrvatske. Zagreb 1900. Nr. 130.

E. M. Müller, Duhovna lekarna za vse, ki hočejo večno živeti. Übersetzt von Fr. Zbašnik. Katoliška Bukvarna. Ljubljana 1889. 110+2 S. Nr. 144.

Naš misijon v Bosni (Prvo letno poročilo). Ljubljana 1911. 24+2 S. Nr. 243.

V. Nazor, Veli Jože. Istarska priča. Hrvatska knjižnica. Hrsg. v. Fran Ilešič. Illustriert v. Saša Šantel. Ljubljana 1908. 96 S. Nr. 145.

A. Nemčić, Izabrana djela. Uredio i uvod napisao Milivoj Šrepel. Sa slikom pjesnikovom. Matica Hrvatska. Zagreb 1898. 464 S. Nr. 147.

Niz novih pripovesti ruskih. Slavenska knjižnica, knjiga 4. Übersetzt von Martin Lovrenčević. Matica Hrvatska. Zagreb 1896. 315+1 S. Nr. 181.

V. Novak, Podgorka. Zabavna knjižnica Matice Hrvatske. Zagreb 1894. Nr. 130.

V. Novak, Dvie pripoviesti. Zabavna knjižnica Matice Hrvatske. Zagreb 1897. Nr. 130.

V. Novak, Posljednji Stipančići. Zabavna knjižnica Matice Hrvatske. Zagreb 1899. Nr. 130.

Novi vedesh sa sméh ino zhaskratenje 'Slovenzom. [Enth.:] „Erklärung einiger [53] vorkommenden Lokalismen, und anderer weniger bekannter Phrasen“" (S. 97f.). Graz 1838. 98 S. Nr. 148.

P. Ogrinec, Setev in žetev. Povest za slovensko ljudstvo. Slovenskih Večernic 33. zvezek. Družba svetega Mohorja. Celovec 1875. 80 S. [Am Deckblatt als 2. Titel angegeben: Jože Andrejčekov, Srečen! Obraz in življenja med vojaki]. Nr. 149.

F. Orožen, Vojvodina Kranjska. Prirodoznanski, politični in kulturni opis (33 podob). Slovenska zemlja. Opis slovenskih pokrajin. Matica Slovenska. Ljubljana 1901. 265+3 S., mit 33 Fotografien. Nr. 150.

E. Orzeszko, Izabrane pripoviesti. Svezak prvi. Slavenska knjižnica, knjiga 8. Übersetzt von Isa Velikanović. Matica Hrvatska. Zagreb 1900. 295+1 S. Nr. 181.

J. K. Pagani, Premišljevanja o presvetem Rešnjem telesu. Družba svetega Mohorja. Celovec 1899. 380+4 S. Nr. 140a.

J. Pajek, Črtice iz duševnega žitka štajerskih Slovencev. Slovenska Matica. Ljubljana 1884. 293 S. Nr. 118.

A. T. Pavičić, Simeon Veliki. Zabavna knjižnica Matice Hrvatske. Zagreb 1897. Nr. 130.

A. T. Pavićić, Ljutovid Posavski. Zabavna knjižnica Matice Hrvatske. Po osnovi Fr. Markovića spjevao A. Tresić Pavičić. Zagreb 1894. Nr. 130.

J. P. Pavlič, Gospod, teci mi pomagat! Molitvene bukve. Družba svetega Mohorja. Celovec 1891. 332+4 S. [Gebetbuch]. Nr. 152.

P. Petrović-Njeguš, Gorski venec Petra II. Petrovića-Njeguša. Prevodi iz svetovne književnosti. Übersetzt von Milan Rešetar, Einl. v. Rajko Perušek. Slovenska Matica. Ljubljana 1907. 299+3 S. Nr. 119b.

R. Pinter, Njemačka književnost do smrti Goetheove. Slike iz svjetske književnosti. Matica Hrvatska. Zagreb 1897. Nr. 153.

V. Podgorc, Domači Zdravnik po naukih in izkušnjah župnika Kneippa. Družba svetega Mohorja. Celovec 1892. 170+6 S. Nr. 154.

V. Podlaz (Hrsg.), Zlate bukve slovenskega vedeža. Slovenskih Večernic 32. zvezek. Družba svetega Mohorja. Celovec 1874. 110+2 S. Nr. 156.

A. Pokorny, Prirodopis rastlinstva s podobami. Übersetzt von Ivan Tušek. Matica Slovenska v Ljubljani. Za spodnje razrede srednjih šol. Drugo predelano in pomnoženo izdanje s 350 podobami. Prag 1872. 244 S. [2. Aufl.], mit 350 Abbildungen. Nr. 157.

A. Pokorny, Prirodopis živalstva s podobami. Fran Erjavec. Za spodnje razrede srednjih šol. Matica Slovenska v Ljubljani. Prag 1872.309 S. [2. Aufl.], mit 490 Abb. Nr. 158.

B. Poparić, O pomorskoj sili Hrvata. Za dobe narodnih vladara. Matica Hrvatska. Zagreb 1899. 140 S. Nr. 159.

F. Povšé, Umni kmetovalec ali splošni poduk, kako obdelovati in zboljšati polje, travnike, vertove in gozde. Družba svetega Mohorja. Celovec 1875, 1876, 1877. [3 Hefte]. Nr. 160. 
A. Praprotnik, Slovenski spisovnik, svetovalec v vseh pisarskih opravilih. Družba svetega Mohorja. Celovec 1879. 372+2 S. Nr. 161.

A. Puškin, Puškinova izabrana djela u hrvatskoj knjizi. Matica Hrvatska. Zagreb 1899. 72+392 S. [Mit einer Einleitung von Milivoj Šrepel]. Nr. 127.

I. Rabar, Poviest najnovjega vremena. Od godine 1815. do godine 1878. Svjetska poviest. Matica Hrvatska. Zagreb 1898. 527 S. [Nr. 163. N]. Nr. 129.

J. R. Razlag, Slovenski pravnik, to je kratki povzetki postav in obrazci ali izgledi raznih pisem. Natisnol Jožef A. Kienreich. Gradec 1862. 160+2 S. Nr. 165.

J. R. Razlag, Pěsmarica. Natisnol Jožef A. Kienreich. Gradec 1863. 208 S. [S. 161-192 cyrillisch; S. 161: Crkveno-ćirilska, gradjansko-ćirilska in latinska azbuka]. Nr. 164.

B. Reisp (Hrsg.) Darinka Zelinkova, Napoleonove Ilirske province 1809 - 1814. Narodni muzej v Ljubljani. Ljubljana 1964. 136 S., mit 48 Bildern und einer Karte [Katalog der Ausstellung im Nationalmuseum Ljubljana 1964]. Nr. 146.

F. Rihar, Marija v zarji slave. Pregled zgodovine Marijinega češčenja. Družba svetega Mohorja. Celovec 1909. 287+1 S. Nr. 167.

J. Rogač, Življenje svetnikov in svetnic Božjih. Družba svetega Mohora. Celovec 1869. 223 (225-448) S. [Vorhanden: 1-9 (1866-1874), 3 (1868) fehlt]. Nr. 142.

V. Rohrman, Poljedelstvo. Splošno poljedelstvo. Slovenskim gospodarjem v pouk. Družba svetega Mohorja. Celovec 1897, 1898. 292+10 S. (144 S., 148+10 S.). Nr. 168.

V. Rohrman, Poljedelstvo (2. del:) Posebno poljedelstvo. Poljedelstvo. Slovenskim gospodarjem v pouk. Družba svetega Mohorja. Celovec 1902. 158+2 S. Nr. 168.

V. Rohrman, F. Dular, Gospodarski nauki (1. knjiga:) Gospodarski nauki. Družba svetega Mohorja. Celovec 1905. 158+2 S. Nr. 138.

Rukopisi M. Gor'kogo. [Handschriftliches von M. Gor'kij; Teil der Titelei fehlt]. Russisch. Moskau, Leningrad 1936. 259+4 S. Fester Einband. Nr. 249.

S. Rutar, Slovenska zemlja. Opis slovenskih pokrajin (1. del:) Poknežena grofija Goriška in Gradiščanska. Prirodznanski, statistični in kulturni opis (22 podob). Matica Slovenska. Ljubljana 1892. 116 S., mit 22 Abb. Nr. 170.

S. Rutar, Slovenska zemlja. Opis slovenskih pokrajin (1. del:) Poknežena grofija Goriška in Gradiščanska. Zgodovinski opis. Matica Slovenska. Ljubljana 1893. 131+1 S., mit 12 Abb. Nr. 170.

S. Rutar, Slovenska zemlja. Opis slovenskih pokrajin (2. del:) Samosvoje mesto Trst in mejna grofija Istra. Matica Slovenska. Ljubljana 1896. 128 S., mit 26 Abb. und 1 Karte. Nr. 169.

S. Rutar, Slovenska zemlja. Opis slovenskih pokrajin (2. del:) Samosvoje mesto Trst in mejna grofija Istra. Matica Slovenska. Ljubljana 1897. 152+8 (129-280) S., mit 12 Bildern und 1 Karte. Nr. 169b.

S. Rutar, Slovenska zemlja. Opis slovenskih pokrajin (3. del:) Beneška Slovenija. Prirodznanski in zgodovinski opis. Matica Slovenska. Ljubljana 1899. 188 S., mit 15 Abb. Nr. 171.

F. Salezij, Filotea ali navod k pobožnemu življenju. Aus d. Franz. übersetzt von Franc Rup. Družba svetega Mohorja. Celovec 1880. 252+4 S. Nr. 173.

M. Samec, Vpliv vpijančljivih pijač na posamni človeški organizem in na človeško društvo v obče. Matica Slovenska. Ljubljana 1880. 42 S. Nr. 174.

Schödler-jeva Knjiga prirode. 1. del [snopič]: Fizika, Astronomija in Kemija (s 361 podobami in 2 mapama). Ubersetzt von Ivan Tušek (Fizika), Vil. Ogrinec (Astronomija), Fran Erjavec (Kemija). Matica Slovenska. Ljubljana 1869, 1870. 534 S. Fester Einband. Nr. 175.

Schödler-jeva Knjiga prirode. 2. snopič: Astronomija in Kemija. Übersetzt von Vil. Ogrinec (Astronomija), Fran Erjavec (Kemija). Matica Slovenska. Ljubljana 1870. 305 (229-534) S., mit 361 Abb. und 2 [?] Karten. Nr. 175.

Schödler-jeva Knjiga prirode. 3. snopič: Mineralogija in Geognozija. Übersetzt von Janez Zajec. Matica Slovenska. Ljubljana 1871. 169 S., mit 193 Abb. Nr. 175.

Schödler-jeva Knjiga prirode. 4. del [snopič]: Botanika in Zoologija. Übersetzt von Ivan Tušek (Botanika), Fran Erjavec (Zoologija). Matica Slovenska. Ljubljana 1875. 440 S., mit 240 bzw. 227 Abb. Fester Einband. Nr. 175. 175.

Schödler-Tušek-Erjavec, Mineralogija in Geognozija (3. zvezek). Ljubljana 1871. Nr. 
Schödler - Tušek - Erjavec, Botanika in Zoologija (4. zvezek). Ljubljana 1875. Nr. 175.

H. Schreiner, Fizika ali nauk o prirodi, 1. knjiga. Družba svetega Mohorja. Celovec 1889. $188+3$ S. Nr. 176.

H. Schreiner, Fizika ali nauk o prirodi, 2. knjiga. Družba svetega Mohorja. Celovec 1891. 190+2 S. Nr. 176.

V. Schweitzer, Navod za snovanje sruštev ter prirejanje shodov. Knjižnica slovenske krščanske socialne zveze. 1902. Nr. 177. N.

F. Seidl, Slovenska zemlja. Opis slovenskih pokrajin (5. del:) Kamniške ali Savinjske Alpe, njih zgradba in njih lice. Poljuden geološki in krajinski opis. Matica Slovenska. Ljubljana 1907, 1908. 255 S., mit Karten, Fotografien und Beilagen. Nr. 170.

J. M. Seigerschmied, Pamet in vera. Slovenskemu narodu $\mathrm{v}$ potrditev njegove vere. Družba svetega Mohorja. Celovec 1901, 1903. 159+1, 190+2 S. [2 Hefte]. Nr. 179.

J. Sernec, Nauk o gospodinjstvu. Družba svetega Mohorja. Ljubljana 1871. 45 S. [in einem Band mit: Janez Sumper, Slovenski Bučelarček]. Nr. 180.

W. Shakespeare, Kralj Lear. Prevodi iz svetovne književnosti. Übersetzt von Anton Funtek. Matica Slovenska. Ljubljana 1904. 160 S. Nr. 119.

W. Shakespeare, Beneški trgovec. Prevodi iz svetovne književnosti. Übersetzt von Oton Zupančič. Slovenska Matica. Ljubljana 1905. 120 S. Nr. 119a.

H. Sienkiewicz, Pripoviesti. Slavenska knjižnica, knjiga 6. Übersetzt von Ivan Gostiša. Zagreb 1898. Nr. 181.

J. Simonič, Kakó postanemo stari? Založil pisatelj v Bistrici-Lembah (Štajersko). Ljubljana 1893. 222 S. Nr. 184.

F. Simonič, Slovenska bibliografija (1. del:) Knjige (1550-1900). Slovenska bibliografija [3 Hefte]. Slovenska Matica. Ljubljana 1903 - 1905. 627 S. Nr. 183.

J. Sket, Slovenska čitanka za peti in šesti razred srednjih šol. Družba svetega Mohorja. Celovec 1892. 404 S. Fester Einband. Nr. 186.

J. Sket, Slovenisches Sprach- und Übungsbuch. Nebst Chrestomathie und slovenischdeutschem und deutsch-slovenischem Wörterverzeichnis. Für den ersten Unterricht. St. Hermagoras-Buchdruckerei. Klagenfurt 1903. 300+4 S. Nr. 185. 189.

M. Slekovec, Duhovni sinovi slavne nadžupnije Konjske. Življenjepisne črtice. 16 S. Nr.

V. Slemenik, Križem sveta. Zgodovinska povest. Družba svetega Mohorja. Celovec 1877. 95+1 S. Nr. 190.

A. M. Slomšek, Krščansko devištvo. Družba svetega Mohorja. Celovec 1894. 393+7 S. Nr. 188.

Slovanski Svet. Hrsg. v. F. Podgornik. Trst 1891. 16 S. [Nur eine Nr. vorh.]. Nr. 244.

Slovenske Večernice za pouk in kratek čas. Družba svetega Mohorja. [Mit Beiträgen von: M. Slekovec, Fr. Kavčič, I. Strukelj, P. Gregorc, Žaljski, J. Fr. Rádinski, I. St.]. Celovec 1894. 143+1 S. Nr. 246.

Slovenski učitelj. Veri, vzgoji, pouku. 6. in 7. letnik. Ljubljana 1905, 1906 [Vorhanden: Jg. 6 (1905): 3, 5, 6, 7, 8, 9, 10, 11; Jg. 7 (1906): 1-5]. Nr. 191.

Socijalizem. [Heft 1-16], Hrsg. v. J. E. Krek. Slovenska kršč.-socijalna zveza. Ljubljana 1901. 512 S. Nr. 79.

J. Staré, Občna zgodovina za slovensko ljudstvo, 1-15. Celovec 1874-1891. Nr. 197. N.

A. Stolc, Križana usmiljenost ali življenje svete Elizabete. Übersetzt von P. Hrisogon Majar. Družba svetega Mohorja. Celovec 1882. 198+2 S. Nr. 196.

J. N. Stöger, Nebeška krona ali premišljevanje o nebesih. Übersetzt von Janez Šmuc. Družba svetega Mohorja. Celovec 1876. 175+1 S. Nr. 192.

J. Stritar, Pod lipo. Knjiga za mladino. Družba svetega Mohorja. Celovec 1895. 190+2 S. Nr. 198.

J. Stritar, Jagode. Knjiga za odrastlo mladino. Družba svetega Mohorja. Celovec 1899. 159+1 S. Nr. 201.

J. Stritar, Zimski večeri. Knjiga za odrastlo mladino. Družba svetega Mohorja. Celovec 1902. 206+2 S. Nr. 200.

J. Stritar, Lešniki. Knjiga za odrastlo mladino. Družba svetega Mohorja. Celovec 1906. 223+1 S. Nr. 199. 
J. Subbotić (Hrsg.), Srbska čitanka za gimnazie. 2. knjiga za 3. in 4. nižu klassu. [Cyrillisch]. Wien 1855. 512 S. Fester Einband. Nr. 202.

J. Sumper, Slovenski Bučelarček. Družba svetega Mohorja. Ljubljana 1871. 92 (49141+3) S. [in einem Band mit Janko Sernec, Nauk o gospodinjstvu]. Nr. 180.

I. Svetina, Jezus Kristus pravi Bog. Založil pisatelj. Ljubljana 1899. 93+2 S. Nr. 207.

Sveto pismo. Pet knjiga Mojsijevih. Übersetzt von Đjuro Daničić. [Cyrillisch]. Pest 1866. Fester Einband. Nr. 203.

P. J. Šafarík, Geschichte der südslawischen Literatur. I. Slowenisches und glagolitisches Schriftthum. II. Illirisches und kroatisches Schriftthum. [Serientitel:] Paul Jos. Safaríks Geschichte der südslawischen Literatur. Aus dessen handschriftlichem Nachlasse herausgegeben von Josef Jireček. Prag 1864, 1865. 192 S., 382 S. Nr. 172.

P. J. Šafarík, Geschichte der südslawischen Literatur. III. Serbisches Schriftthum, 1. Abtheilung. [Serientitel:] Paul Jos. Safaríks Geschichte der südslawischen Literatur. Aus dessen handschriftlichem Nachlasse herausgegeben von Josef Jireček. 1865. 480 S. Nr. 172.

A. Šenoa, Sabrane pripoviesti. [Heft 8] Matica Hrvatska. Zagreb 1897. 378+1 S. Nr. 204.

L. Škufca, Šmarnice ali Romanje v nebeško kraljestvo v Marijinem mesecu. Družba svetega Mohorja. Celovec 1886. 283+5 S. Nr. 187.

M. Šrepel, Preporod u Italiji v 15. i 16. stoljeću. Matica Hrvatska. Zagreb 1899. 283+3 S. Nr. 193.

K. Śtrekelj (Hrsg.), Slovenske narodne pesmi. Slovenska Matica. Ljubljana 1895-1908. [Vorhanden Hefte 1-12 (1895-1908), ohne Heft 11]. Nr. 117.

I. Šubic, Elektrika, nje proizvajanje in uporaba. Matica Slovenska. Ljubljana 1897, 1898. 359 S. Nr. 205.

J. Šuman, Slovenska slovnica po Miklošičevi primerjalni. Matica Slovenska. Ljubljana 1882. 380+1 S. Fester Einband. Nr. 206.

I. Tavčar, Slovenski Pravnik. Družba svetega Mohorja. Celovec 1883, 1885, 1886, 1888. $(626+6)$ S. [Heft 2 fehlt]. Nr. 208.

L. N. Tolstoj, Moč teme. Prevodi iz svetovne književnosti. [Übersetzt von Župančič, Funtek, Perušek]. Slovenska Matica. Ljubljana 1907. 118+2 S. Nr. 119c.

L. Toman, Dr. Lovro Toman. Matica Slovenska. (Uvod: Tomanovo življenje. Popisal Andrej Praprotnik). Ljubljana 1876. 180+3 S. Nr. 121.

J. E. Tomić, Za kralja za dom. Zabavna knjižnica Matice Hrvatske. Zagreb 1894. Nr. 130.

J. E. Tomić, Zmaj od Bosne. Zabavna knjižnica Matice Hrvatske. Zagreb 1898. Nr. 130.

J. E. Tomić, Melita. Zabavna knjižnica Matice Hrvatske. Zagreb 1899. Nr. 130.

I. Tomšić, Poljedelstvo s posebnim ozirom na domače pridelke. Družba svetega Mohora v Celovcu. Ljubljana 1870. 107+3 S. Nr. 209.

M. Torkar, Življenje svetnikov in svetnic Božjih. Celovec (zvezek 7, 8, 9). O.J. Nr. 210a.

M. Torkar, Življenje svetnikov in svetnic Božjih. Družba svetega Mohorja. Celovec 1871, 1874. (3. in 4. (?) del). 476, 629+7 S. Fester Einband. Nr. 210. 211.

D. Trstenjak, Životinje. Diel 8: Ptice. Društvo sv. Jeronima. Zagreb 1895. 124+1 S. Nr. 212.

J. Trunk, Bodi svoje sreče kovač! Družba svetega Mohorja. Celovec 1904. 143+1 S. Nr.

J. S. Turgenjev, Lovčevi zapiski. Übersetzt von Fr. Jos. Remec. Matica Slovenska. Ljubljana 1884. $262 \mathrm{~S}$. Nr. 213.

I. S. Turgenjev, Izabrane pripoviesti, svezak treći. Slavenska knjižnica, knjiga 5. Zagreb 1897. Nr. 181.

I. Tušek (Hrsg.), Štirje letni časi. Iz nemškega po E. A. Rossmässler-ji. Matica Slovenska. Ljubljana 1867. 254+1 S., mit 40 Abb. Nr. 214.

V. Urbas, Dr. Etbin Henrik Costa. Matica Slovenska. Ljubljana 1877. 126 S. Nr. 110.

I. V., Grmanstvo in njega vplív na Slovanstvo v srednjem veku. Matica Slovenska. Ljubljana 1879. $55 \mathrm{~S}$. Nr. 114. Nr. 215.

M. K. Valjavec, Poezije. Uredil Fr. Levec. Slovenska Matica. Ljubljana 1900. 302+2 S.

F. Valla, Poviest srednjega veka. Treći dio: od druge polovine jedanaestoga vieka do god. 1453. Svjetska poviest. Matica Hrvatska. Zagreb 1896. [nur 464 S. vorh., Rest fehlt]. Nr. 129. 
F. Valla, Poviest novoga vieka. Od godine 1453. do godine 1789. Svjetska poviest. Matica Hrvatska. Zagreb 1899. 333 S. Nr. 129.

F. Valla, Poviest novoga vieka. Od godine 1453. do godine 1789. Svjetska poviest. Matica Hrvatska. Zagreb 1900. 503 S. Nr. 129.

J. Verne, Potovanje okolo svetá v 80 dnéh. Übersetzt von Davorin Hostnik. Matica Slovenska. Ljubljana 1878. 145+2 S. Nr. 48.

I. Vesel, Olikani Slovenec. Matica Slovenska. Ljubljana 1868. 132+4 S. Nr. 216.

J. Vesel-Koseski, Raznim delom pesniškim in igrokaznim Jovana Vesela-Koseskiga dodatek. Matica Slovenska. Ljubljana 1879. 65+1 S. Nr. 115. 217.

J. P. Vijanski (Hrsg.), Nanos. Slovenski zabávnik za 1862. Ljubljana 1862. 294+2 S. Nr.

J. Vilikowský, Latinská Poesie Žákovská v Čechách. Sborník Filosofické fakulty university Komenského v Bratislavě. F. f. u. Komenského. Bratislava 1932. 167 S. Nr. 218.

I. Vojnović, Ekvinocij. Zabavna knjižnica Matice Hrvatske. Zagreb 1895. Nr. 130.

J. Volčič, Šmarnice naše ljube Gospé presvetega Serca. Družba svetega Mohorja. Celovec 1879. 333+2 S. [Maipredigten]. Nr. 220.

J. Volčič (Hrsg.), Domači zdravnik. Kratek navod, si zdravje uterditi in življenje podaljšati. Slovenskih večernic 31. zvezek. Družba svetega Mohorja. Celovec 1874. 111+1 S. Nr. 222.

J. Volčič (Hrsg.), Življenje preblažene Device in Matere Marije in njenega prečistega ženina svetega Jožefa. Družba svetega Mohorja. Celovec 1882-1891. Nr. 221.

L. Vončina, Friderik Baraga, prvi kranjski apostoljiski misijonar in škof med Indijani v Ameriki. Družba svetega Mohorja. Celovec 1869. 198+2 S. Nr. 224.

M. Vovčok, Pučke pripoviesti. Slavenska knjižnica, knjiga 7. Übersetzt von August Harambašić [= Marija Evgenija Marković]. Zagreb 1899. [Nr. 227 N] Nr. 181.

J. Vošnjak, Umno kletarstvo. Družba svetega Mohorja. Celovec 1873. 168 S., mit 12 Abb. Nr. 225.

J. Vošnjak, Spomini. 1: 1840-1867. Slovenska Matica. Ljubljana 1905. 251 S. Nr. 226.

J. Vošnjak, Spomini. 2: 1868-1873. Slovenska Matica. Ljubljana 1906. 275+4 S. Nr. 226.

I. Vrhovec, Ljubljanski meščanje v minulih stoletjih. Matica Slovenska. Ljubljana 1886. 283 S. Nr. 229.

I. Vrhovec, Zgodovina Novega Mesta. Matica Slovenska. Ljubljana 1891. 308+8 S. Fester Einband. Nr. 230. 228.

I. Vrhovec, Avstralija in nje otoki. Družba svetega Mohorja. Celovec 1899. 222+2 S. Nr.

I. Vrhovnik, Listi nabožno slovstveni. Knjižnica Družbe sv. Cirila in Metoda. Ljubljana 1902. Nr. 17a.

J. Walter, Sveti Rožni Venec. Poučna in nabožna knjiga za krščansko ljudstvo. Družba svetega Mohorja. Celovec 1897. 316+4 S. Nr. 240.

F. Wiesthaler (Hrsg.), Valentina Vodnika izbrani spisi. Matica Slovenska. Ljubljana 1890. 319 S. Fester Einband. Nr. 231.

J. N. Woldrich, Somatologija ali nauk o človeškem telesu. [Nach der vierten Aufl.] Übersetzt von Fran Erjavec. Matica Slovenska. Ljubljana 1881. 108 S. Nr. 232.

Zgodbe svetega pisma. Hrsg. v. F. Lampe (Janez Ev. Krek). Družba svetega Mohorja. Celovec 1894-1907. Nr. 96.

Zora. Glasilo slovenskega katoliškega dijaštva. Hrsg. v. Ivo Pregelj. Ljubljana 1895-1906 [Vorhanden: 1. Jg.: 3, 4; 2. Jg.: 1, 2, 3, 4; 3. Jg.: 1-10; 4. Jg.: 1, 2, 3, 4, 5; 5. Jg.: 1, 2, 3, 4; 7. Jg.: 2, 3, 4, 5; 8. Jg.: 1, 2, 3, 4, 5, 9. Jg.: 1, 2, 3, 4, 5; 11. Jg.: 1-10; 12. Jg.: 1-12, außer 8]. Nr. 235 .

A. Zupančič, Duhovno pastirstvo. Založil pisatelj. Ljubljana 1885. 903 S. Nr. 238.

A. Zupančič, Pedagogika. Po najboljših virih. Katoliška Bukvarna. Ljubljana 1888. 152 S. Nr. 237.

Žaljski, Na krivih potih. Povest. Slovenskih Večernic 47. zvezek. Družba svetega Mohorja. Celovec 1893. 144 S. Nr. 239.

A. Žlogar (Hrsg.), Zbornik cerkvenih govorov na slavo ss. Cirilu in Metodu. Založil izdatelj. Ljubljana 1886. 236+3 S. Nr. 234. 
Teil 2: „Schrank 99“

(In diesem Teil stehen Auslassungen bei längeren Titeln oder Untertiteln, eigene Kommentare oder die Übersetzungen / Anmerkungen, wie sie sich auf den Karteikarten der Bibliothek finden, in eckigen Klammern. Nr. = Nummerierung in Schrank 99, Galerie im Hauptsaal. Sonstige Angaben und Abkürzungen siehe Teil 1) $30 \mathrm{a}$.

B. Balbinus, Dissertatio apologetica pro slavonica, praecipue bohemica. Pragae 1775 . Nr.

J. E. Bíly, Zgodovina svetih apostolov slovanskih Cirila in Metoda. Janez Majciger. Prag 1863. 105 S. Nr. 3. N.

J. Bleiweis (Hrsg.), Koledarčik Slovenski za leto 1854. Ljubljana 1854. 64 S. Na svitlo dal Janez Bleiweis. Nr. 124.

A. Bohorič, Grammatica oder Windisches Sprachbuch. Clagenfurt 1758. [Bearbeitete Fassung der ersten slowenischen Grammatik von 1584]. Nr. 107.

Božidar. Poučna in kratkočasna povest za slovensko mladino, kakor tudi za odraščene ljudi. Društvo svetega Mohora. Celovec 1853. 113 S. Fester Einband. Nr. 125.

J. Ciringar, Zgodovina svete vere v podobah starega zakona. Celovec 1853. [Glaubensgeschichte in Gestalten des alten Testaments]. Nr. 28.

E. H. Costa, Vodnikov Spomenik. Ljubljana 1859. Nr. 4. N.

P. Dainko, Lehrbuch der windischen Sprache [...]. Grätz 1824. Nr. 67.

G. Dankowsky, Matris slavicae filia erudita vulgo lingua graeca seu Grammatica cunctarum slavicarum et graecarum dialectorum in suis primitivis elementis et inde conflatis organicis formis exhibita, gallicae, italicae, et latinae linguae habita ratione. Posoni 1836, 1837. 171 S. Nr. 22.

G. Drobnič, Vocabulario slovenico-tedesco-italiano. Slovensko-nemško-italianski [...] Besedniak. Ljubljana 1858. [Geschenk von P. Ferdinand Glaser 1884]. Nr. 59a.

C. G. Eberlein, Entwurf eines polnischen Wörterbuchs. 1.Teil: Polnisch-Deutsch. Breslau 1775. Nr. 77.

K. J. Erben, Tomáše ze Štítného knížky šestery o obecnych vécech k'restanskych. Prag 1852. 354+1 S. Des Thomas von Stitné sechs Bücher von den gemeinsamen christlichen Wiegen. Nr. 19a.

F. Erjavec, Domače in tuje živali v podobah. Celovec 1873. [Haus- und wilde Tiere in Abbildungen]. Nr. 62.

A. Foerster (Hrsg.), Cecilia. Cerkvena pesmarica. Celovec 1883. [Geschenk von P. Othmar Berger 1883]. Nr. 60a.

Fröhlich, Rud. A. (= R. A. Veselić), Handwörterbuch der ilirischen und deutschen Sprache. Rečnik ilirskoga i nemačkoga jezika. Wien 1853. [Aus d. Pfarrhofe St. Georgen a/P. 1894]. Nr. 133a.

Glasnik Slovenski. List za literaturo in umetnost. Celovec 1858-1860. [Slovenischer Ausrufer. Blatt für Literatur und Kunst]. Nr. 27.

I. Gršak, Slovenski Štajer. Dežela in ljudstvo. Ljubljana 1870. [Slovenische Steiermark. Land und Leute]. Nr. 17.

A. Janežič, Praktischer Unterricht in der slovenischen Sprache für Deutsche. Celovec 1850. [Nachlass d. P. Wernfried Tettinger 1891]. Nr. 145. N.

A. Janežič (Hrsg.), Slovenska Koleda. Celovec 1858, 1859. [Slovenischer Neujahrsspruch ...]. Uredil Anton Janežič. Nr. 26. N.

J. Jesenko, Prirodoznanski zemljepis. Ljubljana 1874. Nr. 12. 49.

V. S. Karadžić, Srpske narodne pjesme. Wien 1841-1846. [Serbische Volkslieder]. Nr.

H. J. Karlik, Praktische Grammatik zur [...] Erlernung der böhmischen Sprache. Prag 1858. 230 S., mit 4 Tab. Nr. 24.

Koledar družbe sv. Mohora. Družba sv. Mohora (Hrsg.). Celovec 1873, 1875. [St. Hermagoras Calender]. Nr. 33.

Koledar Slovenski. Hrsg. v. A. Praprotnik. Ljubljana 1858. Nr. 73.

D. Kostinčev, Kriesnice. Milošte dragoj nesudejenoj. Karlovac 1865. 127 S. Nr. 97a.

F. H. S. J. Kropf, Index locuples latinarum dictionum, pro Germanicis et Bohemicis [...]. Prag 1753. Nr. 71. 
J. Krsnik, Zgodovina avstrijsko-ogrske monarhije [...]. Ljubljana 1874. Nr. 16.

I. Kukuljević, Slovnik umjetnikah jugoslavenskih. Zagreb 1858, 1859, 1860. 352. [Südslavisches Künstlerlexikon. 4 Hefte bis Porečanin]. Nr. 6.

Letopis Matice Slovenske. [Jahrbuch]. Hrsg. v. Slovenska Matica, Ljubljana 1869-1870, 1871-1873, 1874, 1889, davon die Jgg. 1869-70, 1871-73 Fester Einband. [Die Jgg. 1869, 1870, 1875, 1877-79, 1888 unter Sign. Nr. 95A25, siehe Teil 3]. Nr. 21.

A. T. Linhart, Versuch einer Geschichte von Krain und der übrigen südlichen Slaven. Laibach 1788-1791. Nr. 52, 87.

A. Lukšić, Kriesnice. Milošte dragoj nesudejenoj. Karlovac 1863. 108+3. Nr. 97a.

M. Majar, Slovnica ruska za Slovence. Dunaj 1867. 172 S. [Russische Grammatik für Slovenen]. Nr. 10.

J. Majciger, M. Pleteršnik, B. Raić, Slovanstvo. Prvi del: Občni pregled. - Jugoslovani: Slovenci, Hrvati in Srbi, Bolgari. MS. Ljubljana (1883). 354+2 S., mit 2 Karten. Nr. 11.

Marije Božen Cvet. Celovec 1855. [Gebetbuch]. Nr. 65.

D. Mettenleiter, Ogledalo kerščanskih čednosti. Celovec 1856. [Spiegel christlicher Tugenden]. Nr. 64. $\mathrm{N}$.

F. Miklosich, Lexicon linguae slovenicae veteris dialecti. Vindobonae 1850. 204 S. Nr. 5.

F. Miklosich, Lautlehre der altslovenischen Sprache. Wien 1850. 52 S. Nr. 9.

F. Miklosich, Slavische bibliothek oder beiträge zur slavischen philologie und geschichte. Wien 1851, 1858. 321+1 S., 312+1 S. [Bd. 1 mit Faksimiledruck vor 3. Umschlagseite]. Nr. 7.

F. Miklosich, Formenlehre der altslovenischen Sprache. Wien 1854. 92 S. Fester Einband. Nr. 9a.

F. Miklosich, Über die Sprache der ältesten Russischen Chronisten, vorzüglich Nestors. Wien 1855. 52 S. Nr. 8.

T. Miklóushich, Diogenesh ili szlúga dvéh zgublyenéh bratov. Veszeli Igrokaz vu Petrom Zplyívanyu. Zagreb 1823. 102 S. [Lustspiel]. Nr. 89.

J. Moneta, Enchiridion Polonicum oder Polnisches Handbuch. Handbuch, worinnen zu finden: 1. eine Grammatik, 2. Gespräche [...] aufs neue dem Druck überlassen von Daniel Vogel. Breslau und Leipzig 1774. 880 S. Nr. 76. Nr. 54.

A. J. Murko, Theoretisch-praktische slovenische Sprachlehre für Deutsche. Grätz 1832.

A. J. Murko, Deutsch-Slovenisches und Slovenisch-Deutsches Handwörterbuch. Grätz 1833. 862 S. [Nachlass des P. Felix Stranzl 1890]. Nr. 142.

A. J. Murko, Slovénsko-Némshki in Némshko-Slovénski Rózhni Besédnik. Gradec 1833. 788 S. [Nachlass des P. Felix Stranzl 1890]. Nr. 142.

J. Muršec, Kratka slovenska slovnica za pervence. Gradec 1847. 87+2 S. [Kurze slovenische Grammatik]. Nr. 69.

Načalnoe učenie čelovjěkom" hoteštym" učiti se slavjenskomu čteniju napečátannoe. [Mit cyrillischer Schrift]. Wien 1774. Nr. 103.

Národni Koledar. Ljubljana 1868, 1869. Nr. 15.

J. Negedly, Lehrbuch der böhmischen Sprache für Deutsche. Prag 1830. 412+4 S. Nr. 39.

B. Paulich, Sveta Govorenja za sve Nedilje kroz cilu godinu Sloxena i Recsena u stolnoj cerkvi diakovacskoj. Budim / Ofen 1827. 268 S., 230 S. [Predigten. 2 Teile in 1 Band]. Nr. 13.

V. Podlaz, Zlate bukve slovenskega vedeža. Celovec 1874. [Das goldene Buch des slovenischen Vielwissers]. Nr. 36.

[Marko Pohlin =] Marcus a. S. Antonio [Paduano], Kraynska Grammatica. Laybach 1768. [crainerische Grammatik]. Nr. 98.

M. Rapp, Grundriß der Grammatik des indisch-europäischen Sprachstammes. Stuttgart und Tübingen 1852. 1. Band. [Aus d. Nachlass d. P. Richard Peinlich 1882]. Nr. 22a.

K. Robid, Naravoslovje alj Fiziko. Ljubljana 1849. [Phisik]. Nr. 79.

Rotwellsche Grammatik oder Sprachkunst. Das ist Anweisung, wie man diese Sprache in wenigen Stunden erlernen, reden, und verstehen möge [...]. Frankfurt a. M. 1755. 72 S. Fester Einband. [Im Anschluss: Wörterbuch, von der Zigeuner-Sprache, Nebst einem Schreiben eines Zigeuners an seine Frau, 39 S.; letzteres mit zahlr. slav. Elementen] Nr. 102. 
F. Schiller, Divica Orleanska. Übersetzt von Jovan Koseski-Vesel. Ljubljana 1848. [Jungfrau von Orleans. In slowenischer Bearbeitung von Jovan Koseski-Vesel]. Nr. 29.

F. Schiller, Marija Stuart. [Ins Slowenische Übersetzt von France Cegnar]. Celovec 1861. Nr. 128.

G. Schlag, Neue gründliche und vollständige Polnische Sprach-Lehre. Breslau 1734. 240 S. Fester Einband. Nr. 78.

A. Schleicher, Die Formenlehre der kirchenslavischen Sprache. Erklärend und vergleichend dargestellt. Bonn (Wien, Prag) 1852. 376 S. Fester Einband. Nr. 37.

J. L. Schmigoy, Theoretisch-praktische Windische Sprachlehre. Durch viele Uebungsstücke zum Übersetzen erläutert, mit einer auserlesenen Sammlung von Gesprächen und einem Radical-Wörterbuch versehen. Grätz 1812. 319 S. Fester Einband. Nr. 70.

J. E. Schmitt, Duplná dobropjsebnost Nemecká [...]. Pisek 1819. 267+4 S. [Vollständige deutsche Rechtschreibung, deutsch und böhmisch ...]. Nr. 75.

F. V. Slemenik, Izdajavec. Zgodovinska povest. Celovec 1873. [Der Verräther. Historische Erzählung]. Nr. 61.

V. Slemenik, Križem sveta. Zgodovinska povest. Celovec 1877. [Quer durch die Welt. Histor. Erzählung]. Nr. 45.

A. Slomšek, Zivljenja srečen pot [...]. Celje 1851. [Der glückliche Lebensweg]. Nr. 93.

Slovenska Bčela. [Slovenische Biene]. Celje 1850, 1851, 1853. Nr. 20.

Slovenski Prijatel. Časopis za cerkev, šolo in dom. Celje 1856-1858. [Slovenischer Freund. Zeitschrift für Kirche, Schule und Haus]. Nr. 23.

J. Staré, Občna zgodovina za slovensko ljudstvo. Celovec 1874, 1878-1882. Jgg. 1874, 1878, 1879, 1880, 1881, 1882. [Allgemeine Geschichte des slovenischen Volkes]. Nr. 40.

P. Stóosz, Paztir dobri. Zagreb 1832. [Der gute Hirt. Freude der Lehrer über die Erhebung des Jos. Paleschak zum Canonicus]. Nr. 53.

P. Stóosz, Glasz krichechega vu puschini Horvatykoga szlovztva. Zagreb 1833. [Schmerzensschrei über den Tod des Thomas Miklousich ...]. Nr. 53a.

P. J. Šafarik, Slovanske Starožitnosti. Prag 1862, 1864. [Slavische Altertümer]. Nr. 19.

K. I. Tham, Neuestes [...] böhmisch-deutsches synonymisch-phraseologisches Nazionallexikon oder Wörterbuch. Prag 1805, 1807. Nr. 25. N.

T. Turkuš, Vojska in Mir. Romantična melodrama. Gradec 1871. [Nachlass v. P. Richard Peinlich 1882]. Nr. 135.

J. Ulaga, Zgodovina svete vere v podobah novega zakona. Celovec 1855. [Glaubensgeschichte in Gestalten des neuen Buches]. Nr. 28a.

M. Vertovec, Občna Povestnica. Ljubljana 1853. [Allgem. Weltgeschichte]. Nr. 44.

M. Vertovec, Občna Povestnica ali zgodovina celega sveta. Ljubljana 1863. Nr. 44.

J. Vesel-Koseski, Razne dela pesniške in igrokazne. Ljubljana 1870. [Verschiedene lyrische u. dram. Werke]. Nr. 14.

R. A. Veselić (= Rud. A. Fröhlich), Handwörterbuch der ilirischen und deutschen Sprache. Rečnik ilirskoga i nemačkoga jezika. Wien 1853. [Aus d. Pfarrhofe St. Georgen a/P. 1894]. Nr. 133a.

Vlast'. Časopis pro poučeni a zábavu. Prag 1889-1890. [Geschenk d. P. Joh. Pavec] 1892. Nr. 149.

D. Vogel, Allerley Ergötzlichkeiten oder Sammlung einiger geografischer, historischer, politischer und physischer Lehren und Begebenheiten für den Anfänger der polnischen Sprache. Breslau 1768. 150 S. Fester Einband. [Als zweiter Teil im Band mit Johann Moneta, Enchiridion polonicum, abgedruckt]. Nr. 76.

M. Vouček, Narodni opovedanja. Lemberg 1877. [Volkserzählungen. Mit cyrillischer Schrift (Ruthenisch). Geschenk d. P. Florian Kinnast 1886]. Nr. 101a.

Ein kleines Wörterbüchlein nämlich windisch- und deutscher Sprache [...]. Mahrburg 1789. Nr. 105. N.

Zgodnja Danica. Ljubljana 1868. Nr. 2. N. 
Teil 3:

Kleine Auswahl weiterer slavischer bzw. sprach- und landeskundlich interessanter Bücher aus dem Hauptkatalog der Stiftsbibliothek in Admont

$(\mathrm{Nr} .=$ Numerierung/Sigle im Nominalkatalog. Sonstige Angaben und Abkürzungen siehe Teil 1)

P. S. Barcianu, Theoretisch-praktische Grammatik der romänischen Sprache. Hermannstadt 1858. [Nachlass d. P. Bruno Vogel 1890]. Nr. 99, 139a.

Biblia sacra, ebraice, chaldaice, graece, latine, germanice, sclavonice. Die hl. Schrift des Alten Testaments. Elias Hutter. [in sechs Sprachen: Hebräisch, Chaldäisch, Griechisch, Lateinisch, Deutsch, Slavisch = slovenischer Text aus der Dalmatin-Bibel 1584]. Nürnberg 1599. Vitrine, Hauptsaal.

[E. H.] Costa, Reiseerinnerungen aus Krain. Laibach 1848. Nr. 93A.110.

A. Dimitz, Geschichte Krains von der ältesten Zeit bis auf das Jahr 1873. Laibach 1874 1876. [Nachlass d. P. Richard Peinlich 1882]. Nr. 90 B 71.

Goll, Karstaufforstung. Laibach 1898. Nr. EZ.a.36.

Klun, Archiv für Landesgeschichte des Herzogthums Krain. Laibach 1852. Nr. 47, 669.

Linhart, Versuch einer Geschichte von Krain und der übrigen südlichen Slaven. Laibach 1788-1791. Nr. 52, 87.

A. Luschin v. Ebengreuht, Ueber Orts- und Personennamen in Krain. Laibach 1879. [Nachlass d. P. Richard Peinlich 1882]. Nr. 90 B 98.

Letopis Matice Slovenske. [Jahrbuch]. Hrsg. v. Slovenska Matica. Ljubljana. Jgg. 1869, 1870, 1875, 1877-1879, 1888. Nr. 95A25.

A. Muchar, Das altceltische Noricum. Graz 1821, 1822. Nr. 52, 70.

A. Muchar, Das römische Noricum. Graz 1825-1826. Nr. 52, 74.

A. Muchar, Geschichte des Herzogtums Steiermark. Graz 1844. Nr. 47, 692. 71.

A. Muchar, Versuch einer Geschichte der slavischen Völkerschaften. Graz 1844. Nr. 52,

A. Murko et al., Theses theol. Ohne Ortsang. 1843. [Enthält 13 theol. Thesen verschiedener Autoren: 1. Schiedermayr, 2. Schaefer, 3. Reinisch, 4. Pototschnik, 5. Murko, 6. Kratky, 7. Kohlgruber, 8. Kisser, 9. Hayker, 10. Habermann, 11. Grillwitzer, 12. Grafenstein, 13. Boeck]. Nr. 15.380/4.

Nada. Sarajevo 1896, 1897. [Zeitschrift] (serbisch-kroatisch). Nr. EZ.a.30X.

J. Pajek, Sveti Jožef. Celje 1895. Nr. 97B47Xa.

J. Pajek, Der Dom von Marburg, ein Bild der Glaubenstreue seiner Bewohner. Marburg 1897. [Geschenk d. P. Raimund Miklauc 1900]. Nr. E.Z.d124.

J. Pajek, Die Haupt- und Stadtpfarrkirche St. Georg in Pettau. Marburg 1898. [Geschenk

d. P. Raimund Miklauc 1900]. Nr. E.Z.d124a.

P. v. Radics, Maria Theresia und das Land Krain 1740-1780. Rudolfswert 1881. [Nachlass d. P. Richard Peinlich]. Nr. 90B, 19.

A. Schleicher, Die Darwinsche Theorie und die Sprachwissenschaft. Nr. 45, 13/7.

J. Schönleben, Carniolia antiqua et nova. Labaci 1681. Folio. Nr. 48, 230.

P. J. Šafarik, Slovanske Starožitnosti. Prag 1862, 1864, 1865. Nr. 27-410a.

Topographia ducatus Carniolae. Viennae 1728. Nr. 93A202*.

N. S. Trubetzkoy, Altkirchenslavische Grammatik. Schrift-, Laut- und Formensystem. [= Öst. Akad. d. Wiss., Sitzgsber. 228 Bd., 4. Abt.]. Wien 1954. Nr. 83, C2.

J. W. Valvasor, Topographia Carniolae. Laibach 1679. Nr. 55, 141.

J. W. Valvasor, Topographia Carinthiae. Laibach 1681. Nr. 55, 114.

J. W. Valvasor, Theatrum mortis humanae tripartitum. Laybach 1682. [Schaubühne des menschlichen Todes]. Nr. 70, 328.

J. W. Valvasor, Topographie des Herzogtums Kärnthen. Laibach 1688. Nr. 55, 81.

J. W. Valvasor, Die Ehre des Herzogtums Krain. Laibach 1877-1879. Nr. Cim.B, 48.

Vocabularium Graecum-Latinum. [Griechisch-Lateinisches Wörterverzeichnis. Wiedergabe der griechischen Wörter in lateinischen Buchstaben]. Handschrift auf Pergament. Österreich 12. Jh. Vitrine, Hauptsaal. 
A b stra ct: Slavica (Slovenica) Admontensia. The Slovene cultural life and the national consciousness of Slovene monks in the Styrian Benedictine abbey of Admont in the second half of the 19th century is illustrated on the basis of a surviving book inventory (collection of legacies) of Slovene friars. These friars - appr. ten per cent of all brothers of the Admont monastery - were also active members of Slovene book clubs.

An annotated bibliography records the roughly 500 books. A list of another 100 prints out of the „official“ monastic library's card index might be of interest to Slavonic scientists and bibliophiles.

K e y w ords: Monastic library and archive of Admont, Styria, Austria, 19th century, Slavonic/Slovene books and prints, Slovene Benedictine friars, bibliography, AustroHungarian Empire

Michael Reichmayr

Hungerbergstraße 23/3/7

1190 Wien, Österreich

michael.reichmayr@gmx.at 